\title{
Activities and Opportunities of University Librarians for Full Participation in the Educational Enterprise
}

A questionnaire was distributed to the directors of all members of the Association of Research Libraries and to all other state university libraries inquiring about their attitudes and practices regarding library staff participation in professional and community activities. Seventy-two respondents showed preponderantly favorable attitudes to such activities as teaching, research and publication, consulting, and participating in the work of professional groups. Although there appear to be explainable differences between such activities by librarians and by teaching faculty members, it is clear that most university librarians have reasonable opportunity to engage fully in the educational enterprise.

\begin{abstract}
$\mathrm{T}$ 1 His study is one of a series made to collect and disseminate information regarding the status of librarians and its improvement in colleges and universities. The extent to which librarians have the opportunity (and take advantage of such opportunity when it is available) to participate in professional and community activities has been of concern to librarians for many years. The questionnaire on which this study is based was designed to elicit this information from the larger university and research li-
\end{abstract}

Mr. Kellam is Director and Dr. Barker is Associate Director of Libraries in the University of Georgia. This paper is one in a series of preliminary statements prepared by the Committee on Academic Status of ACRL's University Libraries Section. Its members welcome reader comments on these papers. braries in the United States and Canada. The questionnaire was sent to the directors of all ARL members and to all other state university libraries. Replies were received from seventy-two librarians, most of whom were members of ARL.

\section{General Summary}

The questionnaire was divided into ten areas of activity in which librarians might participate as parts of the educational enterprise. The first question in each section explored the attitudes of the respondents-usually the library directors-toward participation of staff members in a particular activity commonly engaged in by teaching faculty. These questions were expressed in language equivalent to asking, "Do you encourage ...." or "Do you think the library benefits by ..." the given activity. 
The responses showed strong sentiment in favor of all these activities, as follows:

Writing and publication

Per Cent 100

Campus committee and similar assignments

Professional service on local, state, and national basis .

Consulting work

Research

Surveys

96

Leaves of Absence

Participation in non-library professional association work

Participation in non-profession-

al local activities.

Teaching

Though the value of the precise figures may be questioned, there is a clear indication that library administrators, at least in public, strongly favor the participation of their staffs in professional university life. Some of the affirmative replies to these questions about attitude, however, may not have been very hearty, as indicated by the reservations and qualifications expressed by some of the respondents in volunteered comments. From the evidence of similar comments, on the other hand, some of the negative responses also appear to have been rather weak.

Other questions explored the extent to which this generally high estimate of the value of library staff activity is transformed into policies of support in time, money, and other resources. Many of the observations made by respondents indicated that this is difficult for some. Besides his own attitude, it appeared, the administrator has to take into account the attitudes of others, the costs in relation to resources, the peculiarities of the local academic environment, and other elements. Though the findings in the various categories of activity differed, it can be roughly generalized that about three-fourths of the library administrators who favored the involvement of librarians in university activities appeared able and willing to support such involvement at some level and in most categories. This seems indeed like widespread support. The volunteered comments of the respondents, however, indicated that such assistance is often small, it may be extended very selectively, and in some categories the over-all volume of activity on individual campuses is quite low.

\section{Teaching}

Of all the activities in which their staffs might engage, teaching was by far the least popular with library directors. Even so, the 71 per cent who said they encourage it constituted a very substantial sentiment in favor of it. Twothirds of the respondents reported that librarians are given time from their schedules to do teaching, and a remarkable 89 per cent reported that librarians teach courses in their institutions. Librarians were found to teach library science and bibliography only slightly more than subjects outside the library field.

Several points of a qualifying nature should be made. Though most institutions reported some librarians teaching, the comments volunteered by the respondents indicated that the volume of such teaching on each campus tends to be very low. Only a few people on each staff, apparently, possess both the talents and the desire needed for teaching to take place. It is interesting to note that when conditions for teaching exist, library directors usually permit the staff member to go ahead regardless of the director's own attitudes in the matter: 86 per cent of those who encourage teaching reported that they had staff members so engaged, but 78 per cent of those who do not encourage it also reported the same activity. As to time off, the comments revealed that university policy, rather than internal library policy, often determine what arrangements are made, 
or not made, to accommodate teaching. Librarians apparently follow prevailing campus patterns whether that be allowed time, extra compensation, or divided appointments.

\section{RESEARCH}

The response was almost unanimously in favor of encouraging librarians to do research. Most library administrators are also willing to support research activity: 76 per cent said they allowed time for research, and 83 per cent said they gave some sort of financial assistance. About 60 per cent answered that the research need not be related to library operations or probems, but even so the number of librarians reported as working on library subjects exceeded the number working on other subjects by a ratio of about two to one. For the libraries reporting the number of staff members who had engaged in research in the last three years, the range was from zero to twenty-five people, with the median falling at four.

Though the number of institutions supporting the research activities of staff members was high, support seemed, from the comments, to be extended cautiously, with an eye to the value of the project, the promise of the individual, and the cost to the library. A frequently expressed sentiment was that while assistance was available staff members should contribute substantially of their own time. Respondents referred to university and off-campus funding to such an extent that it seems likely that support from sources outside the library is playing a prominent role. The kind of in-house support reported to be given by libraries ran mostly to copying service and other easy-to-give assistance in the same categories suggested in the questionnaire.

\section{Writing and Publication}

Every respondent said that librarians should be encouraged to write and publish. About 78 per cent reported that they allow time for staff members to prepare articles, though a few stated that they also expect writers to work on their own time as well. Seven out of eight library administrators give some kind of recognition for writing and publishing. By far the most common action was to take this activity into account in recommending advancement in rank, salary, or tenure. Other recognition comes in the form of publicity, mention in official reports, and general commendation and encouragement.

\section{Consulting Work and Surveys}

Even though most library administrators regard consulting and surveying as beneficial, the comments indicated that the actual volume of work, free or paid, is very small; and, either because of lack of demand or because the consultant's or surveyor's employer cannot afford it, the volume is not expected to increase much. About 86 per cent of the libraries were reported to give time off for free consulting; 74 per cent would give the time when the consultant is paid. The corresponding proportions for surveys were 83 per cent and 72 per cent. As with some other activities, the staff member who is not given the time seems often to be allowed to charge his time against vacation or to make up the time.

\section{Campus Committee, Council, and BOARD ASSIGNMENTS}

If campus committee work were the chief criterion of librarian identification with the educational enterprise, the conclusion might be reached that librarians have progressed quite far in this direction. All library administrators indicated they were generally in favor of this kind of activity, and 98 per cent reported they had staff members serving on campus bodies.

There seemed to be a variety of attitudes toward actively trying to place librarians on faculty committees. About 
74 per cent reported they make an effort, but some of these commented that their efforts are modest and infrequent. Some said or implied that on their campuses it is unnecessary, even unseemly, to seek assignments since they will be made by proper authority automatically.

Respondents were not asked to tell how many librarians on their campus hold committee posts, but enough volunteered this information to give the impression that the number varies considerably. The nature of assignments also varies greatly. In status they range from campus housekeeping chores, such as parking or safety, to high-level advisory responsibility. Some assignments (like teaching media, publications, archives) are in areas of some relation to librarianship, but others are of general academic interest. Some draw on the specializations of subject librarians, a conspicuous example (twelve instances) being committees for various area study programs. An interesting, but perhaps predictable, group of assignments (ten instances) has been to committees on computer centers, administrative data processing, and campus ID cards.

\section{Professional Service on a Local, State, and National Basis}

Library administrators not only believe in professional service in library organizations but also seem to support it as much as possible. All of them said they give time for professional activities and almost 99 per cent said they pay expenses. The greatest problem, as might be guessed, is the inadequacy of travel budgets. When resources are low, various schemes were reported for curtailing costs: fractional refunding, low per diem allowance, restriction on the number and length of trips, selectivity in persons permitted to travel, rotation of permission to travel, carpooling, selectivity in allowable purposes for travel, and others. Seventy-eight per cent said they paid some expenses to national meetings for staff not on programs or committees. Several who said this, however, indicated that these people were given a lower priority for funds and might in general receive less support than those who had business at the meetings.

\section{Leaves of Absence}

Directors of libraries generally (92 per cent) thought it beneficial to grant leaves of absence to librarians to study elsewhere, and many of them had had some opportunity to reap the benefits. Eighty-two per cent reported that librarians are permitted by university regulations to take leaves of absence for periods of time usual for other faculty members. It was clear, however, from the comments that the leave might be given with full pay, with reduced pay, without pay, or with some combination of these according to a formula; no data were gathered on which pattern prevails. Respondents from 43 per cent of the institutions reported that librarians had been given leave for study or foreign assignments within the last three years. The examples given showed that the travel had been world-wide and for a great variety of purposes.

\section{Participation in Nonlibrary Professional Association Work}

Though library administrators favor (by 92 per cent) staff participation in nonlibrary professional associations, their support for it lagged somewhat behind that for some other categories of activity. Time off is given by 85 per cent of the institutions, but expenses are paid (probably to a very limited extent) by only 47 per cent. The comments suggest that the same budget problems exist in this case as for the library associations, but that participation in these organizations is given a lower priority for funds. The questionnaire asked for examples rather than numbers of staff engaged in nonlibrary professional association activity. The examples, along with comments, 
however, suggest a rather high level of activity and showed-remarkable diversity. The organizations mentioned included AAUP and other educational associations; AHA and other historical societies; a wide variety of subject-specialized associations in the arts, the social sciences, the natural sciences, and technology; and several organizations, such as the National Microfilm Association, connected with, or peripheral to, the library and information fields.

\section{Participation in Nonprofessional LOCAL ACTIVITIES}

Though library directors are less enthusiastic over the civic and other nonprofessional activities of their staffs than over any of the professional activities except teaching, an overwhelming 89 per cent reported they considered it advantageous to their libraries. Few, however, went further than merely to support this kind of activity. Of those who favored such activity, 39 per cent reported that they neither gave time nor paid expenses for it. Just on giving time, the response was fairly divided: 59 per cent give it-at least to some extent-and 39 per cent do not. Very few directors could justify paying any expenses; 86 per cent of those who say they generally approve of these activities reported they do not pay expenses for them.

\section{Comments}

It appears that college and university librarians are given extensive opportunity to participate in the educational enterprise when they have the desire and the capability of doing so. There seems to be an underlying fear, however, that participation in the peripheral activities might detract from the basic service function of the library. It is true that most librarians are required to follow a relatively inflexible schedule which can- not be relaxed to any great extent without causing service to suffer.

Because of the differences in the assignments and responsibilities of librarians and teaching faculty, perhaps librarians should not expect to have the freedom of scheduling that teaching faculty have. The library must accept as its main function responsibility for providing the materials of scholarship and research to students, faculty, and scholars. The library cannot meet this responsibility if its staff is allowed to operate on an unorganized or loosely organized basis such as the teaching faculty may do.

Perhaps there is not so great a problem as would appear at first glance. Probably librarians as a group should not be expected to engage in most of these activities-for example, research and consultation-to the same extent as the faculty. Most faculty either already have or are studying toward the doctorate. Most librarians do not have the doctorate, comparatively few are working toward it, and most library positions do not require it. Many librarians have neither the interest to do extended research nor should it be expected of them because of the nature of their work. Those who are capable and have the desire to do research seemingly have that opportunity in most libraries. Where this opportunity does not exist, the administration would be wise to provide it.

Even if the librarian cannot follow the schedules of the teaching faculty and engage in certain activities to the same extent as the faculty, the nature of his work draws him close to all the educational and research activities of the educational institution. Also he must possess particular academic qualifications and specialized knowledge which the teaching faculty does not have. These justify giving him faculty rank even though certain accommodations must be made. 